\title{
Polish Banking Customer Loyalty: Empirical Data Analysis (Years 2007-2010)
}

Lukasz Skowron, Lublin University of Technology, Poland

Stanislaw Skowron, Lublin University of Technology, Poland

\begin{abstract}
In this article, the authors will try to answer the following question, "How does the customer's loyalty in the banking sector change (at both the structural and quantitative levels) in the face of the financial and banking crisis?"

In order to do that, the authors use their own model of building customer satisfaction and loyalty in the Polish banking sector constructed on the basis of the EPSI (European Performance Satisfaction Index) and ACSI (American Customer Satisfaction Index) models.

This article contains the necessary theoretical background and the precise statistical analysis of the obtained empirical data from the Polish banking sector from the years 2007-2010.
\end{abstract}

Keywords: Customer Satisfaction; Customer Loyalty; Banking Sector

\section{INTRODUCTION}

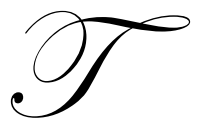

here have been numerous researches conducted, both in Poland and abroad, which indicate that nowadays customer satisfaction and loyalty constitute essential elements in the company's financial performance creation chain ${ }^{1}$. A dynamic increase in the company's turnover of sales and the reduction of the customer service costs are the main benefits of having a strong base of loyal clients.

The observations mentioned above show the importance of having knowledge of the customer satisfaction level. This knowledge is vital in the modern market where the competition often has similar products and business offers. In order to be able to compete effectively on the market, companies must obtain detailed information on the process of building their customers' satisfaction. This information enables the companies to build a loyal and devoted client base in a planned and systematic way.

Therefore, focusing on customer loyalty becomes an essential element of the functioning of modern companies in the market. The strategy of building proper relationships with the customers constitutes a set of rules aimed at maximization of the value of a firm's offer. At the same time, it is worth remembering that the customers' value perceptions (and the factors forming the value in particular) may differ from that of the organization.

This article presents the results of an analysis of customer satisfaction and loyalty measurement of the Polish banking sector conducted in the years 2007-2010.

\footnotetext{
1 Hill N., Alexander J., Pomiar satysfakcji i lojalności klientów, Oficyna Ekonomiczna, Warszawa 2004; Mazurek-Łopacińska K., Satysfakcja klienta - podstawy pomiaru $i$ wykorzystania w polityce przedsiębiorstwa, w: Marketing. Koncepcje, badania, zarzadzanie. Eds. L. Żabińskiego, K. Śliwińskiej, PWE, Warszawa 2002, p. 122; Skowron S., Wptyw satysfakcji i lojalności klienta na wyniki finansowe przedsiębiorstw, w: Marketing przyszłości - Trendy. Strategie. Instrumenty, Eds. Rosa G., Smalec A. Zeszyty Naukowe Uniwersytetu Szczecińskiego nr 594, "Ekonomiczne Problemy Usług" nr 54, Wydawnictwo Naukowe Uniwersytetu Szczecińskiego, Szczecin 2010, p. 377-390; Kristensen, K., Westlund, A.H., Performance Measurement and Business Results, "Total Quality Management”, Vol. 15, No. 5-6, (2004), p. 719-733; Edvardsson B., Gustafsson A., Johnson M.D., Strandvik T., The Effect of Satisfaction and Loyalty on Profits and Growth: Products vs. Services, "Total Quality Management”, 2000 no. 7, p. 917-927; Johnson Michael D. Customer Orientation and Market Action, National Quality Research Center, University of Michigan Business School, Prince Hall, Upper Saddle River, New Jersey 07458.
} 


\section{ESSENCE OF THE CUSTOMER SATISFACTION RESEARCH ${ }^{2}$}

The main aim of all customer satisfaction research is to equip companies with tools enabling them to understand factors that influence clients' purchasing decisions and to help them to determine their business decisions and formulate their future development strategy.

In order to bring profit, customer satisfaction measurements should describe:

- $\quad$ customers' priorities (which needs and expectations are important and to what extent)

- $\quad$ customers' tolerance margin (what constitutes the ideal, expected and acceptable level of the offer quality)

- $\quad$ perceived (experienced) quality of a product or services provided

- $\quad$ comparison of the actual level of quality to customers' priorities or the quality of competitive offers

This approach requires the application of a microeconomic model describing the satisfaction level of individual customers along with the levels of all the factors affecting the customer satisfaction level. In order to build such a model, it is necessary to identify all the factors affecting customer loyalty and satisfaction with a given company's products and/or services. The multidimensional nature of the discussed concepts and the multitude of interdependent factors constitute the main problem concerning customer loyalty and satisfaction measurement.

\section{METHODOLOGY OF THE RESEARCH PROCESS}

The empirical primary research in the Polish banking sector was conducted among a group of 2,249 customers during four research periods ${ }^{3}$. The partakers in trainings, courses, symposia and lectures at universities in the lubelskie, podlaskie, małopolskie, pomorskie, and mazowieckie voivodships constituted the group of respondents of a questionnaire survey. All the analyzed groups of clients were surveyed by means of the same questionnaire. The tool used in the research was built on the basis of the EPSI and ACSI models with the use of a 10 -grade measuring scale ${ }^{4}$. The base model was changed by replacing two areas of quality traditionally used in the EPSI model with three areas of quality (1,2 and 3 as shown in Figure 1).

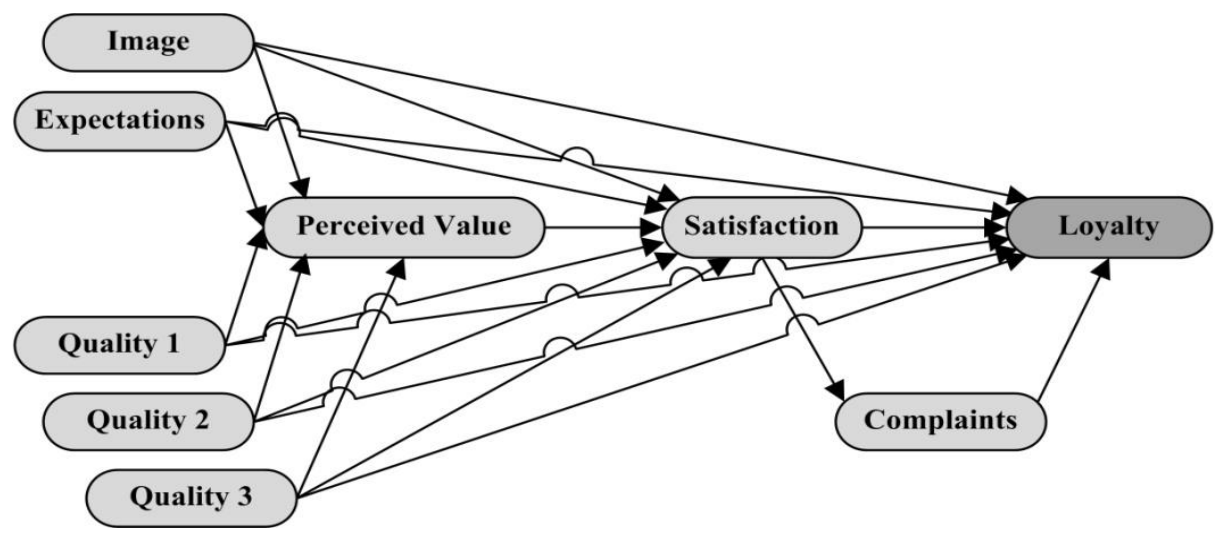

Figure 1: Research Model of the Customer Loyalty and Satisfaction Measurement in the Polish Banking Sector Source: Own work

\footnotetext{
${ }^{2}$ Skowron Ł., Modele ścieżkowe jako przykładowe metody badania satysfakcji i lojalności klientów, w: Marketing przyszłościTrendy. Strategie. Instrumenty. Eds. Rosa G., Smalec A. Zeszyty Naukowe Uniwersytetu Szczecińskiego nr 594, "Ekonomiczne Problemy Usług" no. 54, Wydawnictwo Naukowe Uniwersytetu Szczecińskiego, Szczecin 2010, p. 495-505.

${ }^{3}$ September-December 2007 - 1,024 respondents; November 2008-February 2009 - 544 respondents; October-December 2009 316 respondents and October-December $2010-365$ respondents.

${ }^{4}$ The detailed analysis of the EPSI and ACSI models can be found in Skowron $\mathrm{t}$, Modele ściezkowe jako przykładowe metody badania satysfakcji $i$ lojalności klientów... op. cit.; EPSI Rating 2007, Customer Satisfaction 2006, Pan European Benchmark, In Time AB, Stockholm 2007.

http://www.theacsi.org/index.php?option=com_content\&task=view \&id=48\&Itemid=41
} 
This solution was chosen as the model constructed in this way conveys the specificity of the banking sector. The model used in the research consists of the following areas:

- $\quad$ image (characterized by six research questions)

- $\quad$ expectations (10 research questions)

- $\quad$ quality 1 (describes the availability of banking products and services - 10 research questions)

- $\quad$ quality 2 (describes the real quality of an offer of banking products and services - eight research questions)

- $\quad$ quality 3 (describes the level of customer service - six research questions)

- $\quad$ perceived value (seven research questions)

- $\quad$ customer satisfaction and loyalty (each area characterized by three research questions)

\section{SOCIO-DEMOGRAPHIC ANALYSIS OF THE RESEARCH SAMPLE}

The detailed characteristics of the research sample (for the years 2007-2010) are presented in Table 1.

Table 1: Socio-demographic Data of the Group of Respondents for Years 2007-2010

\begin{tabular}{|c|c|c|c|c|c|}
\hline \multicolumn{2}{|l|}{ Areas } & 2007 & 2008 & 2009 & 2010 \\
\hline \multicolumn{2}{|l|}{ Sample Size (n) } & 1024 & 544 & 316 & 365 \\
\hline \multirow{2}{*}{ Sex } & female & $64,9 \%$ & $68,3 \%$ & $66,5 \%$ & $55,37 \%$ \\
\hline & male & $35,1 \%$ & $31,7 \%$ & $33,5 \%$ & $44,63 \%$ \\
\hline \multirow{4}{*}{ Age } & up to 24 & $57,3 \%$ & $61,7 \%$ & $58,4 \%$ & $63,66 \%$ \\
\hline & $25-30$ & $21,4 \%$ & $19,0 \%$ & $21,5 \%$ & $21,41 \%$ \\
\hline & $31-40$ & $14,5 \%$ & $15,4 \%$ & $12,5 \%$ & $9,30 \%$ \\
\hline & over 40 & $6,8 \%$ & $4,0 \%$ & $7,6 \%$ & $5,63 \%$ \\
\hline \multirow{3}{*}{ Marital status } & single & $64,4 \%$ & $72,2 \%$ & $68,7 \%$ & $72,14 \%$ \\
\hline & married without children & $9,7 \%$ & $7,4 \%$ & $9,5 \%$ & $10,86 \%$ \\
\hline & married with children & $25,9 \%$ & $20,4 \%$ & $21,8 \%$ & $16,99 \%$ \\
\hline \multirow{4}{*}{ Place of residence } & more than 100 thousand inhabitants & $27,9 \%$ & $32,3 \%$ & $28,8 \%$ & $24,79 \%$ \\
\hline & 10-100 thousand inhabitants & $34,7 \%$ & $30,7 \%$ & $30,8 \%$ & $33,43 \%$ \\
\hline & less than 10 th. inhabitants & $9,1 \%$ & $9,9 \%$ & $8,0 \%$ & $8,08 \%$ \\
\hline & village & $28,3 \%$ & $27,1 \%$ & $32,4 \%$ & $33,70 \%$ \\
\hline \multirow{5}{*}{ Income } & below 250 Euro & $42,6 \%$ & $44,1 \%$ & $47,7 \%$ & $37,43 \%$ \\
\hline & 250-500 Euro & $35,2 \%$ & $33,3 \%$ & $35,4 \%$ & $38,86 \%$ \\
\hline & 500-1000 Euro & $17,4 \%$ & $16,1 \%$ & $13,6 \%$ & $20,86 \%$ \\
\hline & 1000-2500 Euro & $3,8 \%$ & $5,1 \%$ & $2,3 \%$ & $2,0 \%$ \\
\hline & over 2500 Euro & $0,9 \%$ & $1,4 \%$ & $1,0 \%$ & $0,86 \%$ \\
\hline
\end{tabular}

Source: Own work on the basis of the results of the authors' research.

The data presented in Table 1 show that the respondents were predominantly young (up to 30 years old approximately $80 \%$ of the research sample in all reporting periods), single, living in big and medium-sized towns and cities or in the rural areas. The majority of respondents had low income per family member (approximately $80 \%$ of the customers of the Polish banking sector participating in the study declared monthly income per family member less than 500 Euro). This depiction of the research sample results from the methodology for respondent selection described above.

\section{NATURE AND FREQUENCY OF USING BANKING SERVICES AND THE LEVEL OF OPTIMISM SHOWN}

The data presented in Table 2 show the nature and frequency of using banking services in the years 20072010 by the respondents participating in the study. 
Table 2: Nature and Frequency of using Banking Services by the Respondents for Years 2007-2010

\begin{tabular}{|c|c|c|c|c|c|}
\hline \multicolumn{2}{|c|}{ Areas } & 2007 & 2008 & 2009 & 2010 \\
\hline \multicolumn{2}{|l|}{ Sample Size (n) } & 1024 & 544 & 316 & 365 \\
\hline \multirow{4}{*}{$\begin{array}{l}\text { The Period of the Client's } \\
\text { Cooperation with a Bank }\end{array}$} & $1-2$ years & $33,9 \%$ & $36,9 \%$ & $28,9 \%$ & $34,92 \%$ \\
\hline & 3-5 years & $39,8 \%$ & $39,6 \%$ & $45,7 \%$ & $36,31 \%$ \\
\hline & 6-10 years & $20,2 \%$ & $16,9 \%$ & $17,1 \%$ & $17,60 \%$ \\
\hline & more than 10 & $6,2 \%$ & $6,7 \%$ & $8,3 \%$ & $11,17 \%$ \\
\hline \multirow{3}{*}{$\begin{array}{l}\text { Frequency of using } \\
\text { Banking Services }\end{array}$} & a few times/week & $25,7 \%$ & $27,9 \%$ & $23,9 \%$ & $35,08 \%$ \\
\hline & a few times/month & $52,9 \%$ & $52,6 \%$ & $58,0 \%$ & $50,55 \%$ \\
\hline & once a month & $20,9 \%$ & $19,5 \%$ & $18,2 \%$ & $14,36 \%$ \\
\hline
\end{tabular}

Source: Own work on the basis of the results of the author's research

The majority of surveyed respondents were the clients of a given bank for 1-2 or 3-5 years. The clients cooperating with one banking institution for more than 10 years account for the smallest proportion of the research group. Moreover, it may be observed that the surveyed clients usually use the services of their banks a few times a month.

Figures 2 and 3 present the structure of the answers concerning the level of optimism shown by the surveyed respondents in relation to the chances of development of the economy and their own economic situation.

While analyzing the data concerning Polish economic growth forecasts, one may note resonable changes concerning opinions of the respondents during the analyzed period. The first clear decrease in optimism was noticed in 2008. This situation may be explained by the banking crisis and negative opinions regarding the state of the Polish economy spread by the media at that time. In the year 2009, the respondents' opinions on the chances for development became more positive, but they did not reach that level before the crisis in 2007. Another decrease in the forecasts was observed in the last reporting period. However, the latter can be the result of numerous sociopolitical problems that occurred in Poland in 2010.

The analysis of the changes in the respondents' economic situation forecast is similar to the opinion regarding Polish economic growth. The main difference concerns the year 2010 in which the respondents estimated their own economic situation to be at the similar level to that from the year 2009 (similar averages for the answers received).

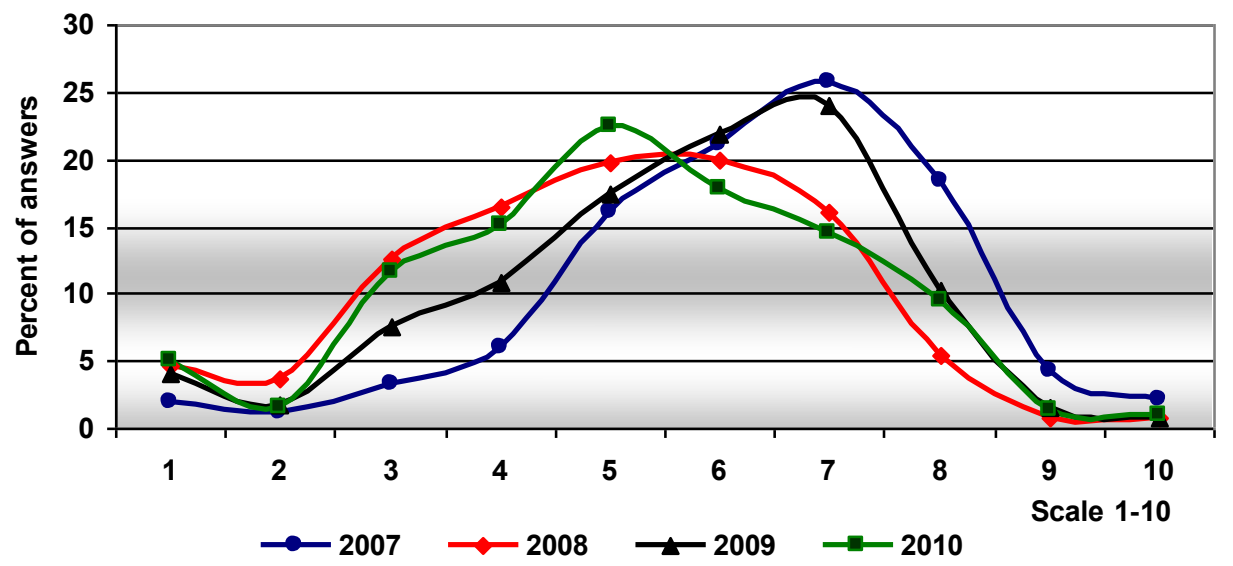

Figure 2: Polish Economic Growth Forecast for Years 2007-2010

Source: Own work on the basis of the results of the authors' research 


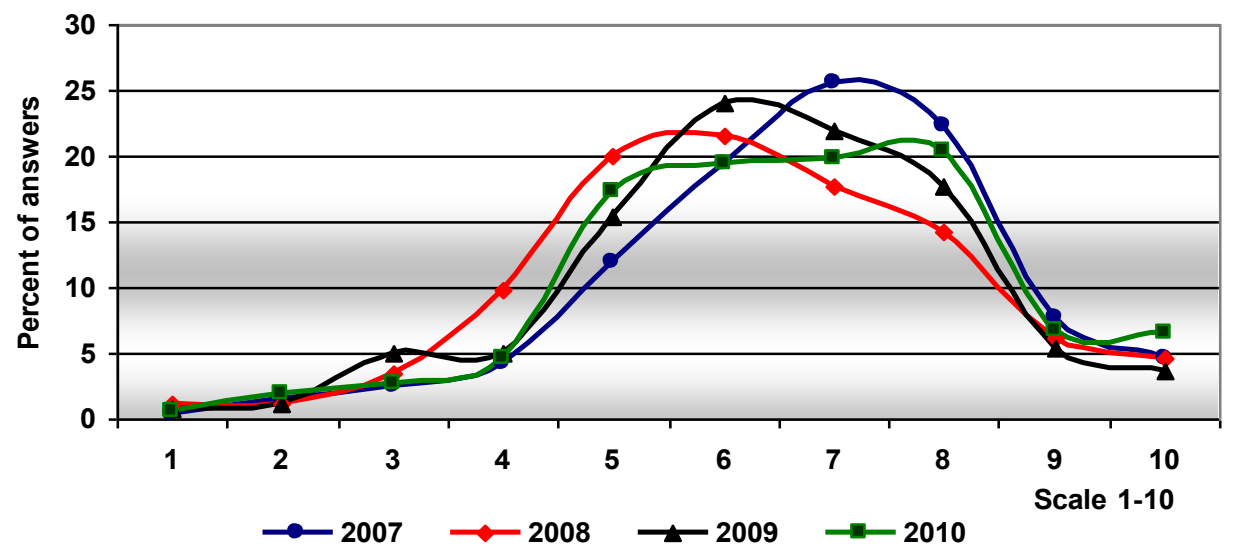

Figure 3: Improvement of the Respondents' Economic Situation Forecast for Years 2007-2010 Source: Own work on the basis of the results of the authors' research

Summing up, it should be highlighted that the research sample mainly consisted of young or middle age people who were studying or working and who had different backgrounds. On the basis of the socio-demographic characteristics of the group of respondents participating in the study and the nature of their relationship with the bank, it is possible to assume that the respondents' age, activeness and level of optimism allow one to believe that the view expressed on the subject matter is rational, which is characterized by proper accuracy and critical approach to the assessment of the problem.

\section{ANALYSIS OF THE RESEARCH MODEL OF CUSTOMER LOYALTY AND SATISFACTION IN THE POLISH BANKING SECTOR}

Figure 4 presents the average figures of the answers received in the individual areas of the model analyzed in this study for the years 2007-2010. As it may be easily noticed in each of the analyzed periods, the expectations of the group of clients participating in this study significantly exceeded the real level of quality (for each of the three types examined) and image. This situation results in the relatively low figures in the areas of "perceived value", "customer loyalty" and "customer satisfaction". Moreover, one may observe that the respondents' expectations in regard to banking services decreased in the subsequent years. From among the analyzed areas of the model, availability of the banking products and services was ranked the lowest by the customers taking part in the study in all the research periods (the area of "quality 1").

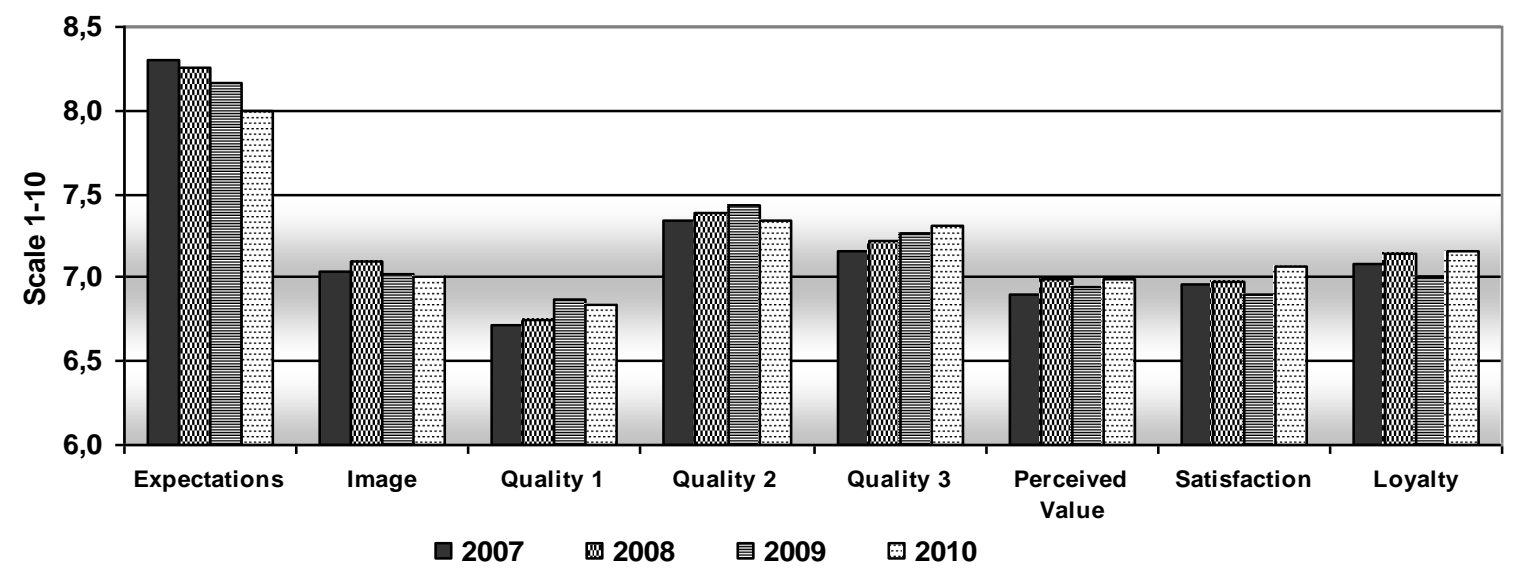

Figure 4: Average Figures of the Answers Received in the Individual Areas of the Model Analyzed in the Study for Years 2007-2010

Source: Own work on the basis of the results of the authors' research 
Figures 5-8 show estimated path models of building customer loyalty and satisfaction in the Polish banking sector in the years 2007-2010. The strengths of the mutual dependencies between the individual areas, which show the whole process of shaping bank-customer relationships, are marked on the models ${ }^{5}$.

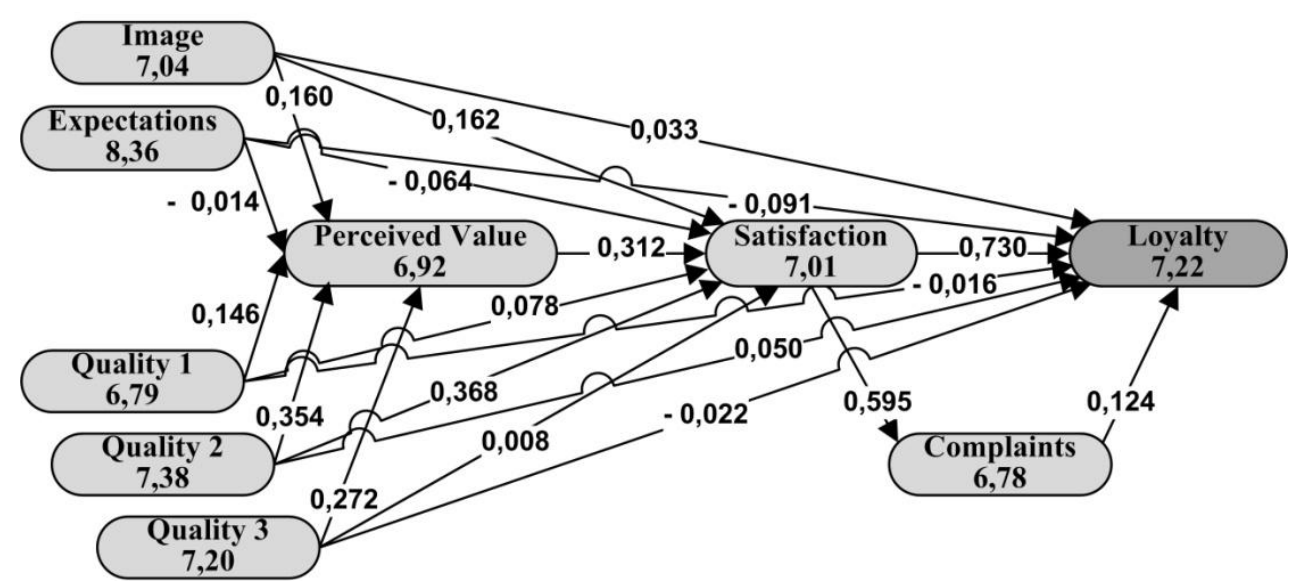

Figure 5: Customer Loyalty Model in the Polish Banking Sector for Year 2007 Source: Own work on the basis of the results of the authors' research

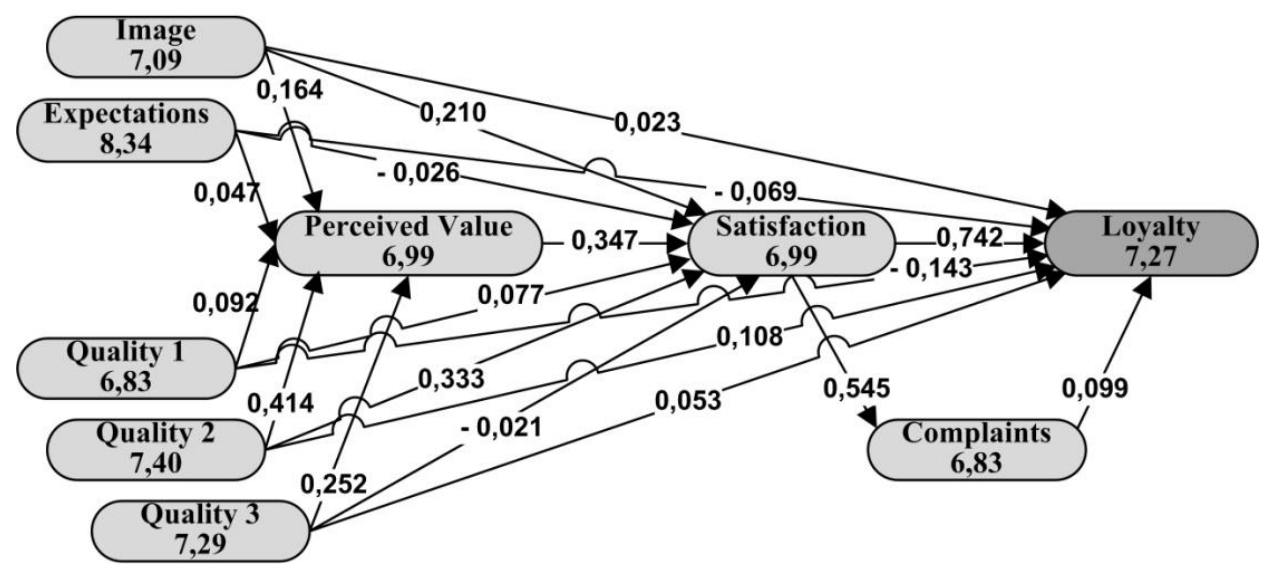

Figure 6: Customer Loyalty Model in the Polish Banking Sector for Year 2008 Source: Own work on the basis of the results of the authors' research

\footnotetext{
${ }^{5}$ In this article, the term "path dependencies" means the dependencies of a correlative nature determined by means of the Partial Least Squares statistical method and obtained by the use of SmartPLS software.
} 


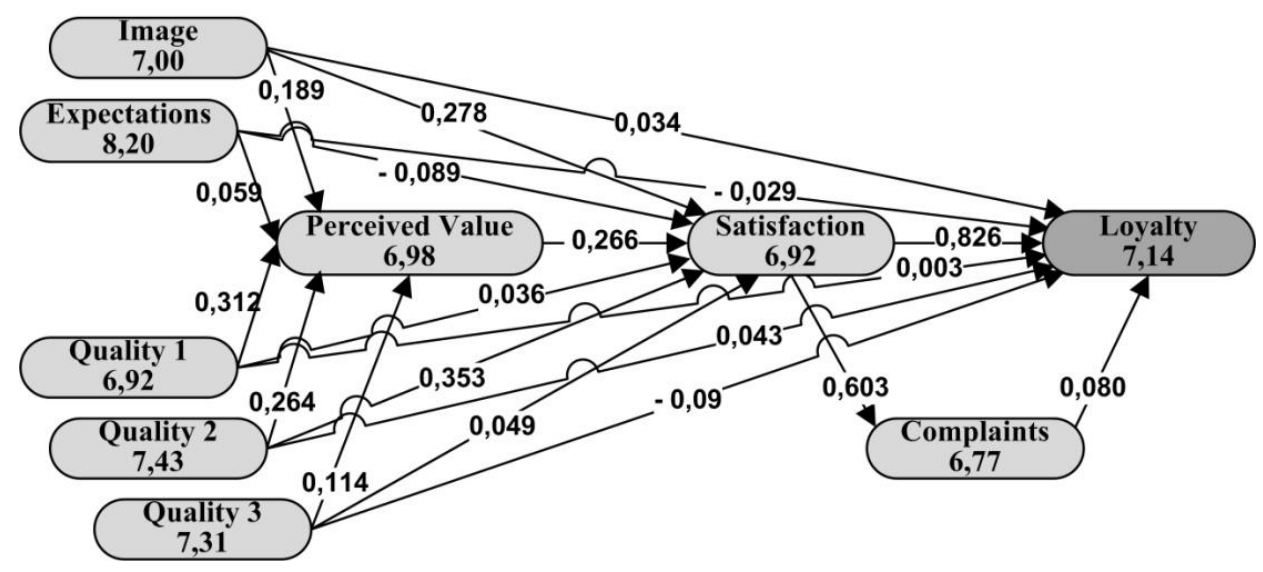

Figure 7: Customer Loyalty Model in the Polish Banking Sector for Year 2009

Source: Own work on the basis of the results of the authors' research

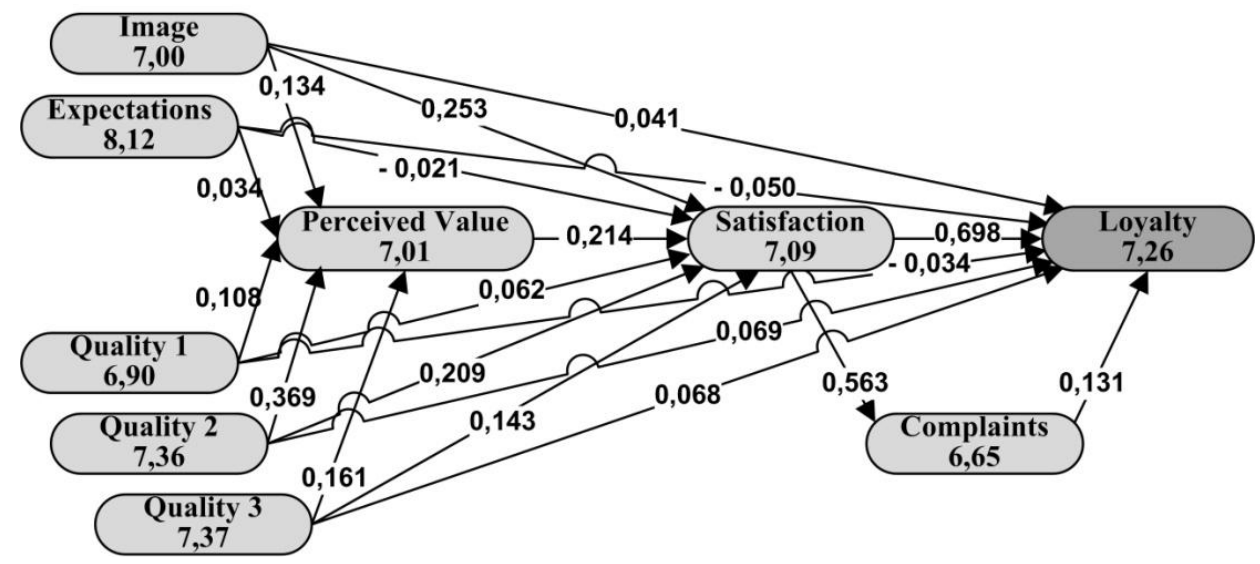

Figure 8: Customer Loyalty Model in the Polish Banking Sector for Year 2010

Source: Own work on the basis of the results of the authors' research

The comparative analysis of the path dependency models for the Polish banking sector shown above allows one to come to the following conclusions:

- $\quad$ There are no statistically significant differences in the values of indices of the individual areas of the model analyzed in this article for the reporting periods. However, one should draw their attention to the gradual decrease in the level of customers' expectations in the years 2007-2010.

- Similarly, as in the case of the analysis of the averages, the path dependencies analysis has also shown that the area of expectations adopts the highest value for the whole Polish banking sector. According to the respondents, the real quality of service (examined in each of the three categories) is lower than expectations.

- In each of the periods analyzed in this study, the area of satisfaction is mainly shaped by the real value of the offer of banking products and services, perceived value, and later, by image. However, it should be noticed that the respondents in the year 2010 attached more significance to the level of customer service as an important factor in building their satisfaction with the services provided by a given outlet.

- Moreover, we can observe that within the years 2007-2010, the customers attached more and more attention to the area of image as an important determinant of building their satisfaction with the choice of a given bank. 
- It is noticeable that the area of satisfaction plays a vital role in the final process of shaping customer loyalty. This situation confirms the utilitarian character of the thesis of the necessity to treat customer satisfaction as an integral component of customer loyalty.

Table 3: Total Effect for the Path Dependencies in the Analyzed Model for Years 2007-2010

\begin{tabular}{|l|c|c|c|}
\hline \multirow{2}{*}{\multicolumn{1}{c}{ Areas }} & \multicolumn{3}{|c|}{ Total Effect 2007 - 2010 } \\
\cline { 2 - 4 } & Perceived Value & Satisfaction & Loyalty \\
\hline Image & $0,16 / 0,16 / 0,19 / 0,13$ & $0,21 / 0,27 / 0,33 / 0,28$ & $0,20 / 0,24 / 0,32 / 0,26$ \\
\hline Expectations & $-0,01 / 0,05 / 0,06 / 0,03$ & $-0,07 /-0,01 /-0,07 /-0,01$ & $-0,15 /-0,08 /-0,09 /-0,06$ \\
\hline Quality 1 & $0,15 / 0,09 / 0,31 / 0,11$ & $0,12 / 0,11 / 0,12 / 0,09$ & $0,08 /-0,06 / 0,11 / 0,03$ \\
\hline Quality 2 & $0,35 / 0,41 / 0,26 / 0,37$ & $0,48 / 0,48 / 0,42 / 0,29$ & $0,43 / 0,49 / 0,41 / 0,30$ \\
\hline Quality 3 & $0,27 / 0,25 / 0,11 / 0,16$ & $0,09 / 0,07 / 0,08 / 0,18$ & $0,05 / 0,11 /-0,02 / 0,21$ \\
\hline Perceived Value & & $0,31 / 0,35 / 0,27 / 0,21$ & $0,25 / 0,28 / 0,23 / 0,17$ \\
\hline Satisfaction & & & $0,80 / 0,80 / 0,88 / 0,77$ \\
\hline Complaints & & & $0,12 / 0,10 / 0,08 / 0,13$ \\
\hline
\end{tabular}

Source: Own work on the basis of the results of the authors' research

The comparative analysis of the total effect (Table 3) confirms the observations from the path dependencies analysis. The most important observations are (for the data from the year 2010 in comparison with the previous years):

- We may claim that the area of satisfaction is statistically more strongly shaped by the areas of image and quality 3 and less strongly shaped by the areas of quality 2, perceived value and expectations. From the statistical point of view, the influence of the other areas does not differ in a significant way.

- $\quad$ the area of customer loyalty is statistically more strongly shaped by the areas of image and quality 3 and less strongly shaped by the areas of customer satisfaction, quality 2, perceived value and expectations.

- $\quad$ it is interesting to note the fact that between the years 2009 and 2010, there was a clear change in the process of shaping both satisfaction and loyalty of the customers of the Polish banking sector who participated in the study. The level of the customers' loyalty is affected to a decisively greater degree by customer service quality assessment, which results in the decrease of importance of the other areas in the discussed process.

Table 4: Value of the Coefficient of Determination $\mathbf{R}^{2}$ for the Modules Described in the Model for Years 2007-2010

\begin{tabular}{|c|c|c|c|c|}
\hline \multirow{2}{*}{ Areas } & \multicolumn{4}{|c|}{$\mathbf{R}^{\mathbf{2}}$ - Coefficient of Determination } \\
\cline { 2 - 5 } & $\mathbf{2 0 0 7}$ & $\mathbf{2 0 0 8}$ & $\mathbf{2 0 0 9}$ & $\mathbf{2 0 1 0}$ \\
\hline Perceived Value & 0,616 & 0,646 & 0,619 & 0,568 \\
\hline Satisfaction & 0,616 & 0,658 & 0,667 & 0,612 \\
\hline Complaints & 0,354 & 0,297 & 0,363 & 0,317 \\
\hline Loyalty & 0,691 & 0,688 & 0,756 & 0,733 \\
\hline
\end{tabular}

Source: Own work on the basis of the results of the authors' research

${ }^{6}$ The coefficient of determination R2 determines what proportion of the variability of dependent variable is caused by the shaping of the independent variable/variables. The coefficient of determination R2 takes on values between 0 and 1 and indicates what part of the variability of the dependent variable $y$ is explained by the model assumed/found.

\section{R2 $=$ RSS/TSS=1-(ESS/TSS)}

Where: RSS - residual sum of squares (the part explained by the model)

ESS - explained sum of squares (the part not explained by the model)

TSS - total sum of squares (TSS=RSS+ESS) 
Variances "R squared" obtained for the individual areas of the model analyzed in this article (Table 4) for the reporting periods indicate that a model constructed in such a way ensures an honest picture of the mechanisms shaping customer satisfaction and loyalty with the usage of a given company's products and/or services. The model shows the variances that occur in the areas discussed in Table $4(61,6 \%$ and $69,1 \%$ in $2007,65,8 \%$ and $68,8 \%$ in $2008,66,7 \%$ and $75,6 \%$ in 2009 , and $61,2 \%$ and $73,3 \%$ in 2010 , respectively).

\section{FINAL CONCLUSIONS}

As far as the analyzed research samples are concerned (2007-2010), it is possible to demonstrate the existence of a main triad (value - satisfaction - loyalty), whose individual elements are related through mutual and statistically significant relationships. Moreover, the area of the real quality of an offer of bank products and services (quality 2) should be considered as the main determinant of the above described triad for the analyzed research samples.

The measurements taken did not demonstrate significant differences in the values of indices of the individual modules of the model analyzed in this study. This situation should be explained by the accumulative character of both customer satisfaction and loyalty. All the changes in the areas of expectations, image and quality modules are quantified by the market and should be reflected in the changes in the values of indices of the individual areas in later reporting periods.

Despite the lack of differences in the values of indexes of the individual modules of the model analyzed in this study, the whole character of the process of building customer loyalty in the Polish banking sector has changed as far as the research samples are concerned. The main difference is constituted by a stronger influence (in the year 2010 in comparison with year 2007) of the areas of image and quality 3 on the final process of shaping customer loyalty in the sector discussed in this study.

The situation assessed may be explained by the fact that when fluctuations in the financial markets occur, clients choose banking institutions mainly on the basis of their stability and the confidence inspired by them (the area of image). Moreover, the possibility for these institutions to provide customers with professional in-depth information concerning all the alternative decisions in the area of a specific banking product offered by a given subject becomes another important factor (the area of "quality 3").

The expectations, as well as the availability and comfort of using individual banking products and services, become less important factors of building potential customer loyalty in comparison with the image of the bank, the real value of the products and services offered and the level of customer service.

\section{AUTHOR INFORMATION}

Lukasz Skowron is an academic teacher in Department of Management at the Lublin University of Technology. He has graduated from two universities - Danish Aarhus School of Business, University of Aarhus and Polish - Lublin University of Technology. Additionally he has also been awarded a PhD degree in management by the Wrocław University of Technology. He is the author of several articles and research papers. In addition he is the owner of the Research Agency “Total Effect”. E-mail: lukasz.m.skowron@gmail.com

Stanislaw Skowron is a professor of management in the Department of Management and a Vice Dean at the Technical University of Lublin. He is the author of several books and more than 100 articles in Polish and international journals. He was also a coordinator of several research programs conducted by the Polish Scientific Research Center. He has received several national academic and scientific awards.

\section{REFERENCES}

1. Edvardsson B., Gustafsson A., Johnson M.D., Strandvik T., The Effect of Satisfaction and Loyalty on Profits and Growth: Products vs Services, "Total Quality Management", 2000 no7, p. 917-927.

2. EPSI Rating 2007, Customer Satisfaction 2006, Pan European Benchmark, In Time AB, Stockholm 2007. 
3. Hill N., Alexander J., Pomiar satysfakcji i lojalności klientów, Oficyna Ekonomiczna, Warszawa 2004.

4. http://www.theacsi.org/index.php?option=com content\&task=view\&id=48\&Itemid=41

5. Johnson Michael D. Customer Orientation and Market Action, National Quality Research Center, University of Michigan Business School, Prince Hall, Upper Saddle River, New Jersey 07458.

6. Kristensen, K., Westlund, A.H., Performance Measurement and Business Results, "Total Quality Management", Vol. 15, No. 5-6, (2004), p. 719-733.

7. $\quad$ Mazurek-Łopacińska K., Satysfakcja klienta-podstawy pomiaru i wykorzystania w polityce przedsiębiorstwa, w: Marketing. Koncepcje, badania, zarządzanie, Eds. L. Żabiński, K. Śliwińska, PWE, Warszawa 2002, p. 122.

8. $\quad$ Skowron Ł., Modele ścieżkowe jako przykładowe metody badania satysfakcji i lojalności klientów, w: Marketing przyszłości - Trendy. Strategie. Instrumenty, Eds. G. Rosa, A. Smalec. Zeszyty Naukowe Uniwersytetu Szczecińskiego nr 594, „Ekonomiczne Problemy Usług” nr 54, Wydawnictwo Naukowe Uniwersytetu Szczecińskiego, Szczecin 2010, p. 495-505.

9. Skowron S., Wpływ satysfakcji i lojalności klienta na wyniki finansowe przedsiębiorstw, w: Marketing przyszłości - Trendy. Strategie. Instrumenty, Eds. G. Rosa, A. Smalec. Zeszyty Naukowe Uniwersytetu Szczecińskiego nr 594, „Ekonomiczne Problemy Usług” nr 54, Wydawnictwo Naukowe Uniwersytetu Szczecińskiego, Szczecin 2010, p. 377-390. 